University of Nebraska - Lincoln

DigitalCommons@University of Nebraska - Lincoln

USDA National Wildlife Research Center - Staff Publications
U.S. Department of Agriculture: Animal and Plant Health Inspection Service

January 2004

\title{
Feasibility of localized management to control white-tailed deer in forest regeneration areas
}

\author{
Tyler A. Campbell \\ University of Georgia, tcampbell@eastfoundation.net \\ Benjamin R. Laseter \\ University of Georgia \\ W. Mark Ford \\ United States Department of Agriculture \\ Karl V. Miller \\ University of Georgia
}

Follow this and additional works at: https://digitalcommons.unl.edu/icwdm_usdanwrc

Part of the Environmental Sciences Commons

Campbell, Tyler A.; Laseter, Benjamin R.; Ford, W. Mark; and Miller, Karl V., "Feasibility of localized management to control white-tailed deer in forest regeneration areas" (2004). USDA National Wildlife Research Center - Staff Publications. 84.

https://digitalcommons.unl.edu/icwdm_usdanwrc/84

This Article is brought to you for free and open access by the U.S. Department of Agriculture: Animal and Plant Health Inspection Service at DigitalCommons@University of Nebraska - Lincoln. It has been accepted for inclusion in USDA National Wildlife Research Center - Staff Publications by an authorized administrator of DigitalCommons@University of Nebraska - Lincoln. 


\title{
Feasibility of localized management to control white-tailed deer in forest regeneration areas
}

\author{
Tyler A. Campbell, Benjamin R. Laseter, W. Mark Ford, \\ and Karl V. Miller
}

\begin{abstract}
The deleterious effects of white-tailed deer (Odocoileus virginianus) on forest regeneration are well documented in many forested systems, but potential solutions to these problems on remote landholdings are limited in number and scope. Localized management proposes that a persistent area $\left(<2 \mathrm{~km}^{2}\right)$ of low density can be created by removing all individuals within matriarchal social groups of white-tailed deer. Our objective was to assess the feasibility of using localized management as a tool within forest regeneration areas. We present a comparison of seasonal home-range and core-area size and site fidelity of 148 radiomonitored female white-tailed deer in a forested landscape of the central Appalachians of West Virginia. We also characterized seasonal movements and dispersal. Adult female winter home-range size exceeded those of summer and autumn. Female deer displayed high fidelity, with home-range and core-area overlap being less in autumn than in summer or winter. Dispersal occurred in 1 of $28(3.6 \%)$ female fawns and no deer $>1$ year old dispersed. Female white-tailed deer on our study site meet the a priori assumptions of localized management. We assert that experimental manipulations based on localized management concepts are prudent.
\end{abstract}

Key words Appalachians, dispersal, localized management, Odocoileus virginianus, site fidelity, white-tailed deer

Natural resource managers have long recognized that white-tailed deer (Odocoileus virginianus) can alter forested ecosystem processes. The deleterious impacts of white-tailed deer to forest regeneration are well documented (Tilghman 1989, Horsley et al. 2003), but investigations of potential solutions to these problems on remote landholdings are limited in number and scope. The fact that many deer populations across the eastern United States are considered locally or regionally overabundant suggests that traditional management strategies are not universally successful (Witmer and deCalesta 1992, Rutberg 1997).

Researchers have proposed an alternative approach to managing overabundant white-tailed deer populations based on their matriarchal social organization (Porter et al. 1991, Mathews and Porter 1993, McNulty et al. 1997) and the rose-petal hypothesis (Mathews 1989). This management approach has been termed localized or "surgical" because it focuses on the removal of family units in relatively small areas (Porter et al. 1991). Localized management has received little scientific evaluation, in part because it contradicts both traditional and theoretical paradigms (Fretwell 1972, Pulliam 1996, Kohlmann and Risenhoover 1997). However, white-tailed deer social behavior often is oversimplified and should be considered when managing overabundant deer populations (Miller and Ozoga 1997).

Address for Tyler A. Campbell, Benjamin R. Laseter, and Karl V. Miller: Warnell School of Forest Resources, University of Georgia, Athens, GA 30602, USA; e-mail for Campbell: tcampbell@smokey.forestry.uga.edu. Address for W. Mark Ford: United States Department of Agriculture, Northeastern Research Station, Box 404, Parsons, WV 26287, USA. 
Specifically, hypotheses have been developed which propose that localized management can be used to create persistent (10-15-year) areas $(<2$ $\mathrm{km}^{2}$ ) of low density by removing all individuals within a group of white-tailed deer (Porter et al. 1991). Central to localized management are the assumptions that female deer exhibit low dispersal, are highly philopatric, and display high site fidelity. In the only experimental test of localized management, McNulty et al. (1997) found that after removing a group of female deer $(n=14)$ in an unhunted, seasonally migratory herd, adjacent female deer ( $n$ =9) did not shift their home ranges closer to the removal area for $\geq 2$ years. This evidence has led other researchers who observed high site fidelity and low dispersal within female deer to discuss its potential as a management tool (Kilpatrick and Spohr 2000, Grund et al. 2002).

The implications of McNulty et al. (1997) appear to merit consideration in several management contexts. Apparent management scenarios include suburban areas and parks (Porter et al. 1991). Localized management also appears well-suited for forestry applications, particularly on remote landholdings that are not easily accessed by hunters. Selectively removing social groups in and around recent or planned forest regeneration areas could cause 1) a persistent zone of low deer density, 2) a localized reduction in deer herbivory pressure, and 3) enhanced seedling and sprout establishment and growth for adequate stocking of desirable woody species. Complementing the use of localized management in forestry applications, research from the southern Appalachians suggests that clearcuts are used little by deer when sprouts and seedlings reach $1.5 \mathrm{~m}$ (Blymyer and Mosby 1977), which occurs 2-3 growing seasons after timber harvest in the Appalachians (Della-Bianca and Johnson 1965). Similarly, Stoeckeler et al. (1957) concluded that a prolonged period of low deer density is needed in second-growth hardwood-hemlock stands in northeastern Wisconsin to permit successful regeneration and adequate growth of seedlings.

Because the applicability of localized management is dependent on high site fidelity of females, and the size of a localized removal area depends on home-range size (Porter et al. 1991), we conducted an investigation of female movements in a hunted, high-density deer herd to assess the feasibility of implementing a localized management plan. We report seasonal home-range and core-area size and site fidelity among 3 age classes of female white- tailed deer. Furthermore, we characterize seasonal movements and dispersal within female deer.

\section{Study area}

We conducted our study on the 3,360-ha MeadWestvaco Corporation's Wildlife and Ecosystem Research Forest (MWWERF) in Randolph County, West Virginia (38 $42^{\prime} \mathrm{N}, 8^{\circ} 3^{\prime} \mathrm{W}$ ). The MWWERF was established in 1994 to examine the influence of industrial forestry on ecological and ecosystem processes in the central Appalachians. Occurring within the Unglaciated Allegheny Mountain and Plateau Physiographic province, the MWWERF was characterized by steep side slopes, narrow valleys, and broad plateau-like summits where elevations ranged from 700-1,200 m (Smith 1995). Precipitation averaged 170-190 $\mathrm{cm} /$ year, with average snowfall $>300 \mathrm{~cm} /$ year (National Oceanic and Atmospheric Administration 1998-2002). Forest cover was primarily an Allegheny hardwood-northern hardwood type that was under both even-aged (75\%) and uneven-aged (25\%) management. Timber was harvested on 40-80-year rotations, and clearcuts ranged from 8-19 ha in size. Forest communities were dominated by American beech (Fagus grandifolia), yellow birch (Betula alleghaniensis), maple (Acer spp.), and black cherry (Prunus serotina). At lower elevations elements of the mixed mesophytic forest included yellow poplar (Liriodendron tulipifera), northern red oak (Quercus rubra), American basswood (Tilia americana), and black birch (B. lenta). Red spruce (Picea rubens)-eastern hemlock (Tsuga canadensis) communities occurred at higher elevations and along riparian areas. A shrub layer of greenbrier (Smilax spp.), rosebay rhododendron (Rbododendron maximum), and mountain laurel (Kalmia latifolia) occurred throughout.

Pre-harvest white-tailed deer densities and sex ratios during our study were estimated as 12-20 deer $/ \mathrm{km}^{2}$ and 6-18 adult males: 100 adult females, respectively (Langdon 2001). Abomasal parasite counts suggested the deer population was at or near nutritional carrying capacity (Fischer 1996).

\section{Methods}

\section{Capture and radiotelemetry}

We captured deer from January to April using modified Clover traps (Clover 1954) and rocket nets (Hawkins et al. 1968) baited with whole kernel 
1126 Wildife Society Bulletin 2004, 32(3):1124-1131

corn. We immobilized and ear-tagged all deer upon capture. We used both physical restraint and chemical (2.2 mg xylazine hydrochloride [Lloyd Laboratories, Shenandoah, Ia.] / kg body weight) immobilization techniques. For deer chemically immobilized, we used $1 / 2$ intravenous and $1 / 2$ intramuscular injections of yohimbine hydrochloride (Wildlife Laboratories, Fort Collins, Colo.; $0.3 \mathrm{mg} / \mathrm{kg}$ body weight) as a reversal agent. Female deer were radiocollared (Advanced Telemetry Systems, Isanti, Minn.). We determined age of deer as fawns, yearlings, or adults via tooth eruption, replacement, and wear (Severinghaus 1949). All capture and handling procedures were approved by the University of Georgia's Institutional Animal Care and Use Committee (Permit No. A2002-10119-0).

We collected diurnal and nocturnal radiotelemetry data year-round. We estimated deer locations using radio receivers and hand-held, 4-element Yagi antennas. We took compass azimuths from fixed geo-referenced telemetry stations. Prior to generating an estimate, we pinpointed deer locations with 3-8 azimuths. To generate deer location estimates, we recorded 2 simultaneous azimuths that produced an angle of $90 \pm 40^{\circ}$. We used CALHOME (Kie et al. 1996) to generate UTM coordinates of estimated deer locations. We considered individual deer locations $\geq 10$ hours apart independent and attempted to locate each deer 3-4 times/week.

We assessed the accuracy of our location estimates by randomly placing transmitters at geo-referenced points in areas commonly occupied by deer. Each observer then recorded compass bearings from 5 telemetry stations. To increase accuracy we omitted all estimated locations in which the observer was $\geq 3 \mathrm{~km}$ from estimated deer location.

\section{Home-range and core-area estimation}

We used the fixed-kernel method (Worton 1989) to generate $95 \%$ home-range areas and 50\% core areas using the Animal Movement extension (Hooge and Eichenlaub 1997) of ARCVIEW ${ }^{\circledR}$ (Environmental Systems Research Institute 1999). We used least-squares cross validation as the smoothing parameter on the kernel distributions (Silverman 1986). Home range and core areas were generated for summer (May-Sep), autumn (Oct-Dec), winter (Jan-Apr), and annually (Jun-May). Home-range and core-area polygons were overlaid onto a coverage map of the MWWERF using MeadWestvaco's Forest Research Information System $\left(\right.$ FRIS $^{\circledR}$ ) and ARCVIEW. We used the minimum convex polygon (MCP) bootstrap function of Animal Movement to determine number of locations needed to obtain stable homerange areas. We randomly selected 30 deer and completed 100 iterations of home-range size as a function of the number of locations (3-50). Mean number of locations needed to obtain a stable MCP area was $32(\mathrm{SE}=1)$. Consequently, we omitted deer with $<32$ locations/season. The MCP home range method is sensitive to number of locations used (Jennrich and Turner 1969). Therefore, $\geq 32$ locations represent a conservative lower limit for the fixed-kernel method. We included deer in the analysis only if they were radiomonitored throughout the duration of a year or season.

We quantified site fidelity similar to Lesage et al. (2000) for philopatry by calculating the area of home range and core areas that were reused (i.e., overlap) in the following year or season of the following year. If deer were monitored for 3 years, we calculated areas of overlap among all 3 years. We used ARCVIEW to determine overlapping areas. We determined percent overlap by dividing the overlap area by the mean of the associated home range or core area and multiplying by $100 \%$.

We defined seasonal movements as the temporary movement to a distinct non-overlapping home range (Dusek et al. 1989). We defined dispersal as the permanent movement to a separate home range $>4 \mathrm{~km}$ away from the natal range (Nelson and Mech 1992). We determined the distance between core areas of migratory and dispersing deer using ARCVIEW.

\section{Statistical analysis}

We determined seasonal differences in homerange and core-area sizes within yearlings and adults (both considered "adults" for this analysis) using an analysis of variance (ANOVA) with repeated measures. Our ANOVA model considered individual deer as a block and season as the repeated factor. We blocked by deer to make the analysis more sensitive by removing variation among deer from the error term (Kuehl 1994). Statistical significance was accepted at $\alpha=0.05$. We used Tukey's honestly significant difference as a multiple range test.

We completed the following analyses on a subsample of deer $(n=91)$ that we radiomonitored for $>1$ season or year. We compared annual and seasonal home-range and core-area sizes between yearlings as adults (2-year-old) and between fawns as yearlings (winter only) with a paired $t$-test or signed 
Table 1. Mean (SE) summer (May-Sep), autumn (Oct-Dec), winter (Jan-Apr), and annual (Jun-May) home-range (HR, 95\% fixed-kernel) and core-area (CA, 50\% fixed-kernel) size (ha) of female white-tailed deer monitored as yearlings and 2-year-olds on the MeadWestvaco Wildlife and Ecosystem Research Forest, West Virginia from 1999-2002.

\begin{tabular}{|c|c|c|c|c|c|c|c|c|}
\hline \multirow[b]{2}{*}{ Age } & \multicolumn{2}{|c|}{ Summer $(n=18)$} & \multicolumn{2}{|c|}{ Autumn $(n=18)$} & \multicolumn{2}{|c|}{ Winter $(n=15)$} & \multicolumn{2}{|c|}{ Annual $(n=12)$} \\
\hline & HR & $\mathrm{CA}$ & $\mathrm{HR}$ & $\mathrm{CA}$ & $\mathrm{HR}$ & $\mathrm{CA}$ & HR & $\mathrm{CA}$ \\
\hline Yearling & $109(20)$ & $21(4)$ & $115(29)$ & $19(6)$ & $127(51)$ & $24(10)$ & $98(15)$ & $17(4)$ \\
\hline 2-year-olds & $95(15)$ & $18(5)$ & $93(15)$ & $16(3)$ & 175 (49) & $28(9)$ & $113(18)$ & $19(5)$ \\
\hline
\end{tabular}

rank test, depending on the normality of the distributions (SAS Institute 1989). We selected these analyses because they consider the dependence of the samples. We used completely randomized ANOVAs to compare percent home-range and corearea overlap 1) among ages in both consecutive and nonconsecutive winters, 2) between ages in consecutive years annually, 3) among seasons in nonconsecutive years within adults, and 4) between consecutive and nonconsecutive periods annually within adults. We used a 2-factor ANOVA to determine differences in percent home-range and corearea overlap among seasons and between ages within consecutive periods. To maintain experiment-wise error rate of $\alpha=0.05$ in ANOVA models for home-range and core-area overlap, we compared related tests following Bonferroni correction (Sokal and Rohlf 1995).

\section{Results}

We generated home ranges and core areas of 148 ha). female white-tailed deer from 26,274 location estimates in 1999-2002. Mean ( \pm SE) number of locations/year/deer was $125 \pm 15$. Mean number of locations/season/deer was $42 \pm 3$. Adult winter home-range size $(n=110$, $\bar{x}=133 \pm 12$ ha) exceeded $\left(F_{2,409}=3.10, \quad P=0.05\right)$ those of summer ( $n=90, \bar{x}=100 \pm 8$ ha) and autumn $(n=86, \bar{x}=99 \pm 10 \mathrm{ha})$. Similarly, adult core-area size was greater $\left(F_{2,409}=4.26, P=0.02\right)$ in winter $(\bar{x}=24$ \pm 3 ha) than autumn $(\bar{x}=15 \pm 2$ ha).

Home-range size for yearlings maturing to 2-yearolds did not differ during summer $\left(t_{17}=0.72, P=\right.$ $0.48)$, autumn $\left(t_{17}=0.95, P=0.36\right)$, winter $\left(t_{14}=\right.$ $-1.66, P=0.12)$, and annually $\left(s_{11}=-22, P=0.09\right.$, Table 1). Mean core-area size for yearlings maturing to 2-year-olds during summer $\left(t_{17}=0.66, P=0.52\right)$, autumn $\left(t_{17}=0.64, P=0.53\right)$, winter $\left(t_{14}=-0.78, P=\right.$ $0.45)$, and annually $\left(t_{11}=-0.52, P=0.61\right)$ did not differ. During winter deer had smaller $\left(s_{26}=-91, P=\right.$ $0.03)$ home ranges as fawns ( $\bar{x}=90 \pm 15$ ha) than as yearlings $(\bar{x}=123 \pm 20 \mathrm{ha})$. Similarly, winter core areas of fawns $\left(\bar{x}=15 \pm 3\right.$ ha) were less than $\left(s_{26}=\right.$ $-93, P=0.02)$ their core areas as yearlings $(\bar{x}=21 \pm 3$

Among deer monitored for 2 years, percent overlap in winter home range was $\geq 50 \%$ and did not differ $\left(F_{2,44}=2.86, P=0.07\right)$ among fawns maturing to yearlings, yearlings maturing to adults, and adults (Table 2). Similarly, for deer monitored for 2 years, percent overlap in winter core area did not differ $\left(F_{2,44}=2.01, \quad P=\right.$

Table 2. Mean (SE) white-tailed deer home-range (HR, 95\% fixed-kernel) and core-area $50 \%$ fixed-kernel) overlap (\%) for summer (May-Sep), autumn (Oct-Dec), winter (Jan-Apr), and annually (Jun-May). Deer were radiomonitored from 1999-2002 on the MeadWestvaco Wildlife and Ecosystem Research Forest, West Virginia.

\begin{tabular}{|c|c|c|c|c|c|c|c|c|c|}
\hline \multirow{2}{*}{$\begin{array}{l}\text { Years } \\
\text { monitored } \\
\text { Period }\end{array}$} & \multicolumn{3}{|c|}{$\begin{array}{l}\text { Fawns maturing to } \\
\text { yearlings or adults }\end{array}$} & \multicolumn{3}{|c|}{$\begin{array}{l}\text { Yearlings maturing } \\
\text { to adults }\end{array}$} & \multicolumn{3}{|c|}{ Adults } \\
\hline & $n$ & $\mathrm{HR}$ & $\mathrm{CA}$ & $n$ & $\mathrm{HR}$ & $\mathrm{CA}$ & $n$ & $\mathrm{HR}$ & $\mathrm{CA}$ \\
\hline \multicolumn{10}{|l|}{ Two } \\
\hline Summer & & & & 17 & $64(3)$ & $53(5)$ & 20 & $64(3)$ & $50(6)$ \\
\hline Autumn & & & & 17 & $50(3)$ & $31(4)$ & 20 & $44(3)$ & $21(5)$ \\
\hline Winter & 17 & $50(4)$ & $26(5)$ & 4 & $67(8)$ & $22(11)$ & 26 & $59(3)$ & $39(5)$ \\
\hline Annual & & & & 12 & $71(3)$ & $49(7)$ & 18 & $66(4)$ & $50(6)$ \\
\hline \multicolumn{10}{|l|}{ Three } \\
\hline Summer & & & & 1 & 56 & 47 & 22 & $42(2)$ & $21(3)$ \\
\hline Autumn & & & & 1 & 25 & 10 & 21 & $31(3)$ & $6(2)$ \\
\hline Winter & 11 & $39(2)$ & $17(5)$ & 1 & 47 & 29 & 25 & $47(2)$ & $18(3)$ \\
\hline Annual & & & & 1 & 57 & 34 & 17 & $56(3)$ & $37(5)$ \\
\hline
\end{tabular}
$0.15)$ among fawns maturing to yearlings, yearlings maturing to adults, and adults. In deer monitored for 3 years, percent overlap in winter home range was $\geq 39 \%$ and did not differ $\left(F_{2,34}=2.90, P=0.07\right)$ among fawns maturing to adults, yearlings maturing to adults, and adults. Likewise, for deer monitored for 3 years, percent overlap in winter core 


\section{Wildlife Society Bulletin 2004, 32(3):1124-1131}

area did not differ $\left(F_{2,34}=0.28, P=0.76\right)$ among fawns maturing to adults, yearlings maturing to adults, and adults. In deer monitored for 2 years, percent overlap in annual home range and core area did not differ $\left(F_{1,28}=0.79, P=0.38\right.$; and $F_{1,28}=$ $0.04, P=0.85$, respectively) between yearlings maturing to adults and adults (Table 2). For deer monitored for 3 years, adults had less home-range $\left(F_{2,65}=11.58, P<0.001\right)$ and core-area $\left(F_{2,65}=8.11\right.$, $P=0.001)$ overlap during autumn $(\bar{x}=31 \pm 3 \%$ and $\bar{x}$ $=6 \pm 2 \%$, respectively $)$ than during summer $(\bar{x}=42 \pm$ $2 \%$ and $\bar{x}=21 \pm 3 \%$, respectively) or winter $(\bar{x}=47 \pm$ $2 \%$ and $\bar{x}=18 \pm 3 \%$, respectively). We also observed seasonal differences in deer monitored for 2 years. Within these deer both yearlings and adults had less overlap in home range $\left(F_{2,114}=12.60, P<0.001\right)$ and core area $\left(F_{2,114}=14.32, P<0.001\right)$ during autumn than in summer or winter (Table 2), with no differences $\left(F_{2,114}=2.98, P=0.06\right.$; and $F_{2,114}=$ $0.30, P=0.75$, respectively) in age observed. No differences occurred between adults monitored for 2 years and 3 years in overlap of annual home range $\left(F_{1,33}=3.97, P=0.06\right)$ and core area $\left(F_{1,33}=3.44, P=\right.$ 0.07).

We observed distinct home ranges among seasons in 6 of 148 (4.1\%) deer. Movements occurred between 28 November and 25 April, and deer remained on winter ranges an average of $83 \pm 18$ days. Mean distance between summer and winter core areas was $4.2 \pm 0.3 \mathrm{~km}$. We observed dispersal in 1 of 28 (3.6\%) fawns. The single dispersal event occurred 12 May prior to the median parturition date for the population. Distance between natal and permanent core areas was $15.4 \mathrm{~km}$. No deer $\geq 1$ year old dispersed.

\section{Discussion}

For localized management to be a feasible, both logistical and behavioral assumptions have to be met. A priori logistical assumptions include the ability to remove (through capture or shooting) sufficient numbers of female deer. Although no previous study involving the capture of white-tailed deer has been reported from the central Appalachians, our capture success suggests that deer in this heavily forested and remote region may be suitable to control through localized management.

A priori behavioral assumptions of localized management include high site fidelity and low dispersal within female deer (Porter et al. 1991, McNulty et al. 1997). Our data indicate that female deer from the central Appalachians display high site fidelity. For example, winter home-range overlap for fawns monitored for 2 and 3 years were 50 and 39\%, respectively (Table 2 ). Additionally, within yearlings and adults monitored for $\leq 3$ years, overlap of annual home ranges was $\geq 56 \%$, suggesting that a significant portion of female deer ranges are traditional. Where white-tailed deer are seasonally migratory, fidelity to summer home ranges exceeds that of winter home ranges (Tierson et al. 1985, Van Deelen et al. 1998, Lesage et al. 2000). We found deer in the central Appalachians to display less fidelity to autumn home ranges and core areas than during other seasons. Possible explanations for this include annual variability in hard-mast availability (McShea and Schwede 1993), activities of hunters (Marchinton and Hirth 1984, VerCauteren and Hygnstrom 1998), and breeding behaviors (Hölzenbein and Schwede 1989, Labisky and Fritzen 1998) associated with the autumn season.

Our data also support the second behavioral assumption of localized management. Female deer from the central Appalachians exhibited low dispersal rates, an observation consistent with other studies of white-tailed deer in homogeneous habitats (Tierson et al. 1985). Aycrigg and Porter (1997) suggest that low female dispersal in the Adirondack Mountains may be a function of low fawn recruitment, resulting in few agonistic behaviors, and minimal forest fragmentation, resulting in adequate forest cover for reproducing females. These also could explain our low rates of dispersal. However, our deer densities were 3-4 times greater than those from the Adirondacks (McNulty et al. 1997, Langdon 2001), thus increasing the opportunity for aggressive interactions and providing additional evidence that female dispersal is voluntary (Woodson et al. 1980, Nelson and Mech 1992). Our data agree with the assertion that female dispersal is a function of habitat continuity (Nixon et al. 1991).

Porter et al. (1991) noted that prior to formulating a localized management plan, several questions should be addressed, including the area size necessary in which to apply. This is of particular interest in forestry applications because forest regeneration areas are finite in size. For localized management to be applicable within regeneration areas, the size of the removal area should be large enough to ensure coverage of the regeneration area and small enough to be feasible (Campbell et al. 2002). In the central Appalachians, we believe the condition of regener- 
ation area coverage is satisfied because all regeneration areas are smaller than individual deer home ranges and the collective home ranges of matrilineal groups (Laseter et al. 2002). For example, clearcut regeneration areas on the MWWERF range from approximately 13-25 ha, constrained by MeadWestvaco's internal ecosystem-based multipleuse forestry plan and in compliance with the Sustainable Forestry Initiative, which is $>4$ times smaller than individual deer and matrilineal group home ranges.

Porter et al. (1991) addressed the issue of removal area size by suggesting that the minimum size of the removal area depends upon seasonal home-range size, degree of overlap among individuals of social groups, and number of individuals within social groups. However, because localized management does not require extensive knowledge of deer social structure (McNulty et al. 1997), we simply focused on seasonal home-range size. In our study adult females had the largest home ranges during winter (133 ha), as opposed to other seasons (approximately $100 \mathrm{ha}$ ). Therefore, in the central Appalachians the minimum removal area size could approximate $1.3 \mathrm{~km}^{2}$, an area consistent with suggestions from the Adirondacks (Porter et al 1991, McNulty et al. 1997). McNulty et al. (1997) demonstrated that a social group within an area of $1.4 \mathrm{~km}^{2}$ can be removed efficiently. Despite the higher densities on the MWWERF, we believe that a removal area of $1.3 \mathrm{~km}^{2}$ is likewise small enough to be feasible. This removal area would, of course, be centered over a group of planned or newly created forest regeneration areas.

Our observed seasonal movements were notably uncommon and short in distance. In northern Michigan, Van Deelen et al. (1998) attributed low incidence of migration to high adult female mortality and the lack of associated learning by fawns (Nelson 1998), or to conditional migration, which suggests that deer may or may not migrate, depending on winter conditions (Nelson 1995). We believe the latter is a better explanation for the seasonal movements we observed because adult female survival rates are high year-round (Campbell 2003). Nelson (1998) suggests that learning acts indirectly as the selective mechanisms in the adaptiveness of migratory behavior. Our data appear to support this: deer 960 and deer 963 moved together (presumably an adult and yearling offspring), and seasonal movements in deer 962 were observed in only 1 of 2 winters.

\section{Management implications}

Female white-tailed deer from the central Appalachians meet the a priori assumptions of localized management (i.e., they display high site fidelity, exhibit low dispersal and high philopatry, and can be readily captured). Furthermore, few deer maintained distinct seasonal ranges, suggesting that deer would have little opportunity to encounter and colonize a localized removal area (Porter et al. 1991). Consequently, we suggest that localized management could be a feasible technique for reducing deer herbivory around forest regeneration areas in the central Appalachians. We assert that experimental manipulations based on localized management concepts are prudent. We propose that localized removals within the central Appalachians may be most effective if conducted during the winter because 1) deer can be captured and removed efficiently during winter, 2) recently conceived fawns would still be in utero, and 3) home-range sizes are greatest during winter, thus increasing the probability of removing entire social groups.

Acknowledgments. We appreciate the financial support provided by the MeadWestvaco Corporation and the United States Department of Agriculture's National Research Initiative Program (grant 00-35101-9284). We are grateful to J. L. Crum, P. D. Keyser, and D. A. Osborn for providing logistical assistance and support. Editorial comments to earlier drafts of this manuscript were provided by R. J. Warren, J. P. Carroll, and R. L. Hendrick. We are indebted to the 30 field technicians who assisted in data collection. Deer were captured and handled under the auspices of Scientific Collection Permits 43-1999, 16-2000, and 2001.008 from the West Virginia Division of Natural Resources.

\section{Literature cited}

AYCRIGG, J. L., AND W. F. PORTER. 1997. Sociospatial dynamics of white-tailed deer in the central Adirondack Mountains, New York. Journal of Mammalogy 78: 468-482.

BLYMYER, M. J., AND H. S. MosBy. 1977. Deer utilization of clearcuts in southwestern Virginia. Southern Journal of Applied Forestry August: 10-13.

CAmpbell, T.A. 2003. Movement ecology of white-tailed deer in the central Appalachians of West Virginia. Dissertation, University of Georgia, Athens, USA.

Campbell, T. A., B. R. Laseter, D. A. Osborn, W. M. Ford, and K. V. MiLLER. 2002. Localized management of white-tailed deer within forest regeneration areas of the central Appalachians. 


\section{Wildife Society Bulletin 2004, 32(3):1124-1131}

Proceedings of the International Deer Biology Congress 5: 37.

Clover, M. R. 1954. A portable deer trap and catch-net. California Fish and Game 40: 367-373

Della-Bianca, L., ANd F. M. Johnson. 1965. Effect of an intensive clearing on deer-browse production in the southern Appalachians. Journal of Wildlife Management 29: 729-733.

Dusek, G. L., R. J. Mackie, J. D. Herriges, And B. B. Compton. 1989. Population ecology of white-tailed deer along the lower Yellowstone River. Wildlife Monographs 104.

ENVIRONMENTAL Systems Research Institute. 1999. ARCVIEW. Version 3.2. Environmental Systems Research Institute, Redlands, California, USA.

FIsCHER, J. R. 1996. White-tailed deer herd health check on the Westvaco Wildlife and Ecosystem Research Forest. Final Report to the West Virginia Division of Natural Resources.

Fretwell, S. D. 1972. Populations in a seasonal environment Princeton University Press, Princeton, New Jersey, USA.

Grund, M. D., J. B. MCANinCh, AND E. P. Wiggers. 2002. Seasonal movements and habitat use of female white-tailed deer associated with an urban park. Journal of Wildlife Management 66: $123-130$.

Hawkins, R. E., L. D. Martoglio, and G. G. Montgomery. 1968 Cannon-netting deer. Journal of Wildlife Management 32: 191-195.

HÖLZENBEIN, S., AND G. SCHWEDE. 1989. Activity and movements of female white-tailed deer during the rut. Journal of Wildlife Management 53:219-223.

Hooge, P. N., AND B. Eichenlaub. 1997. Animal movement extension to ARCVIEW. Version 1.1. United States Geological Survey, Anchorage, Alaska, USA.

Horsley, S. B., S. L. Stout, ANd D. S. DeCalesta. 2003. White-tailed deer impacts on the vegetation dynamics of a northern hardwood forest. Ecological Applications 13: 98-118.

JENNRICH, R. I., AND F. B.Turner. 1969. Measurement of non-circular home range. Journal of Theoretical Biology 22: 227-237.

KIE,J. G., J.A. BALDWIN,AND C. J. EvANS. 1996. CALHOME: a program for estimating animal home ranges. Wildlife Society Bulletin 24: 342-344.

KilPATRICK, H. J., AND S. M. SPOHR. 2000. Spatial and temporal use of a suburban landscape by female white-tailed deer. Wildlife Society Bulletin 28: 1023-1029.

Kohlmann, S. G.,AND K. L. RisenhoOvER. 1997. White-tailed deer in a patchy environment: a test of the ideal-free-distribution theory. Journal of Mammalogy 78: 1261-1272.

KuEHL, R. O. 1994. Statistical principles of research design and analysis. Duxbury Press, Belmont, California, USA.

LABISKY, R. F., AND D. E. FRITZEN. 1998. Spatial mobility of breeding female white-tailed deer in a low-density population. Journal of Wildlife Management 62: 1329-1334.

LANGDON, C.A. 2001. A comparison of white-tailed deer population estimation methods in West Virginia. Thesis, West Virginia University, Morgantown, USA.

Laseter, B. R., T. A. Campbell, D. A. Osborn, K. V. Miller, And W. M FORD. 2002. Spatio-temporal characteristics of female whitetailed deer in the central Appalachians of West Virginia Proceedings of the Annual Southeastern Deer Study Group 25: 34 .

Lesage, L., M. Crête, J. Hout, A. Dumont, And J. Ouellet. 2000 Seasonal home range size and philopatry in two northern white-tailed deer populations. Canadian Journal of Zoology 78: $1930-1940$.

Marchinton, R. L., AND D. H. HiRTH. 1984. Behavior. Pages
129-168 in L. K. Halls, editor. White-tailed deer ecology and management. Stackpole Books, Harrisburg, Pennsylvania, USA.

Mathews, N.E. 1989. Social structure, genetic structure and antipredator behavior of white-tailed deer in the central Adirondacks. Dissertation, State University of New York, Syracuse, USA.

Mathews, N. E., AND W. F. Porter. 1993. Effects of social structure on genetic structure of free-ranging white-tailed deer in the Adirondack Mountains. Journal of Mammalogy 74: 33-43.

McNulty, S. A., W. F. Porter, N. E. Matthews, and J. A. Hill. 1997. Localized management for reducing white-tailed deer populations. Wildlife Society Bulletin 25: 265-271.

McSheA, W. J., AND G. SCHWEdE. 1993. Variable acorn crops: responses of white-tailed deer and other mast consumers. Journal of Mammalogy 74:999-1006.

Miller, K.V., AND J. J. Ozoga. 1997. Density effects on deer sociobiology. Pages 136-150 in W.J. McShea, H. B. Underwood, and J. H. Rappole, editors. The science of overabundance: deer ecology and population management. Smithsonian Institution, Washington D.C., USA.

National Oceanic and Atmospheric Administration. 1998-2002. Climatological data, West Virginia. Volumes 106-110. Environmental Data Service, Asheville, North Carolina, USA.

NeLson, M. E. 1995. Winter range arrival and departure of whitetailed deer in northeastern Minnesota. Canadian Journal of Zoology 73: 1069-1076

Nelson, M. E. 1998. Development of migratory behavior in northern white-tailed deer. Canadian Journal of Zoology 76 : 426-432.

Nelson, M. E., AND L. D. Mech. 1992. Dispersal in female whitetailed deer. Journal of Mammalogy 73: 891-894.

Nixon, C. M., L. P. Hansen, P. A. Brewer, and J. E. Chelsvig. 1991. Ecology of white-tailed deer in an intensively farmed region of Illinois. Wildlife Monograph 118.

Porter, W. F., N. E. Matthews, H. B. Underwood, R. W. SAge, JR., AND D. F. BEHREND. 1991. Social organization in deer: implications for localized management. Environmental Management 15: 809-814

Pulliam, H. R. 1996. Sources and sinks. Empirical evidence and population consequences. Pages 45-69 in O. E. Rhodes, R. K. Chesser, and M. H. Smith, editors. Population dynamics in ecological space and time. University of Chicago Press, Chicago, Illinois, USA

RUTBERG,A.T. 1997. The science of deer management: an animal welfare perspective. Pages 37-54 in W. J. McShea, H. B. Underwood, and J. H. Rappole, editors. The science of overabundance: deer ecology and population management. Smithsonian Institution, Washington D.C., USA.

SAS INSTITUTE. 1989. SAS/STAT user's guide. Version 6. Fourth edition. SAS Institute, Cary, North Carolina, USA.

Severinghaus, C.A. 1949. Tooth development and wear as criteria of age in white-tailed deer. Journal of Wildlife Management 13: 195-216.

Silverman, B.W. 1986. Density estimation for statistics and data analysis. Chapman Hall, London, United Kingdom.

SMITH, D.W. 1995. The southern Appalachian hardwood region. Pages 173-225 in J.W. Barrett, editor. Regional silviculture of the United States. John Wiley and Sons, New York, New York, USA.

SOKAL, R. R., AND F. J. RoHLF. 1995. Biometry. Third edition. W. H. Freeman, New York, New York, USA

Stoeckeler, J. H., R. O. Strothmann, AND L. W. Krefting. 1957. 
Effect of deer browsing on reproduction in the northern hardwood-hemlock type in northeastern Wisconsin. Journal of Wildlife Management 21: 75-80.

Tierson, W. C., G. F. Mattreld, R. W. Sage, Jr., and D. F. Behrend. 1985. Seasonal movements and home ranges of white-tailed deer in the Adirondacks. Journal of Wildlife Management 49 : 760-769.

Tilghman, N. G. 1989. Impacts of white-tailed deer on forest regeneration in northwestern Pennsylvania. Journal of Wildlife Management 53:524-532.

Van Deelen,T. R., H. Campa, III, M. Hamady, AND J. B. Haufler. 1998. Migration and seasonal range dynamics of deer using adjacent deeryards in northern Michigan. Journal of Wildlife Management 62: 205-213.

VerCauteren, K. C., ANd S. E. Hygnstrom. 1998. Effects of agricultural activities and hunting on home ranges of female white-tailed deer. Journal of Wildlife Management 62 : 280-285.

WitMER, G.W., AND D. S. DECALESTA. 1992. The need and difficulty of bringing the Pennsylvania deer herd under control Proceedings of the Eastern Wildlife Damage Control Conference 5: 130-137.

Woodson, D. L., E.T. ReEd, R. L. Downing, AND B. S. MCGINNES. 1980 Effect of fall orphaning of white-tailed deer fawns and yearlings. Journal of Wildlife Management 44: 249-252.

WORTON, B. J. 1989. Kernel methods for estimating the utilization distribution in home-range studies. Ecology 70 164-168.

Tyler A. Campbell (photo) is a research wildlife biologist with the National Wildlife Research Center's Kingsville, Texas field station. He received a B.S. in wildlife and fisheries managemen from Texas Tech University, an M.S. in range and wildlife management from Texas A\&M University-Kingsville, and a Ph.D. in forest resources from the University of Georgia. His research has focused on wildlife habitat and nutritional relationships. He has been a member of The Wildlife Society since 1993 and a Certified Associate Biologist since 1998. Benjamin R. Laseter is a Ph.D. candidate in the Warnell School of Forest Resources at the University of Georgia. He received his B.S. from the

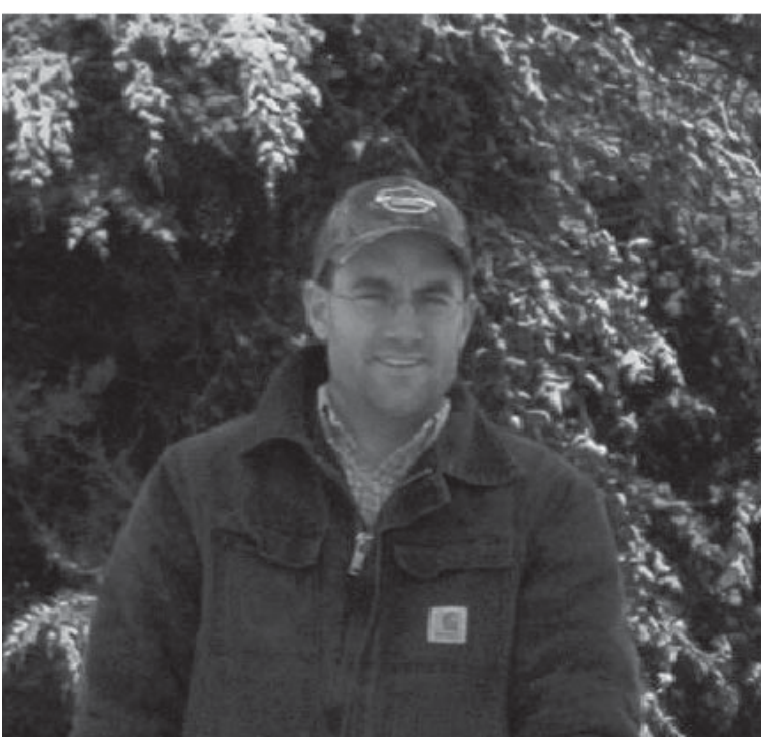

University of Georgia and his M.S. from the University of Memphis. His research interests include social and genetic structure of wildlife populations. W. Mark Ford is a research wildlife biologist with the USDA Forest Service's Northeastern Research Station at the Fernow Experimental Forest in West Virginia. He received his Ph.D. in forest resources from the University of Georgia in 1994. His research focus is on wildlife management and forest community ecology in the southern and central Appalachians. He has been a member of The Wildlife Society since 1987 and a Certified Wildlife Biologist since 1998. Karl V. Miller is a professor of wildlife ecology and management in the Warnell School of Forest Resources at the University of Georgia. He and his students focus their research interests on the interactions among physiology, social behavior, communication, and management of white-tailed deer and on the influence of forest management practices on habitat conditions for game and nongame wildlife in the southeastern United States.

Associate editor: Euler 